\title{
Learning-focused Teacher Leadership: The Professional Development School (PDS) Advantage
}

\author{
Dr. Jana Hunzicker, Bradley University
}

\begin{abstract}
Professional development schools (PDS), a specific type of school-university partnership, offer distinctive learning environments for teachers by encouraging innovation and modeling best instructional practices. In PDS partnerships, opportunities abound for teachers to assume learning-focused leadership roles such as team lead, instructional coach, and professional developer. Drawing from the book Teacher Leadership in Professional Development Schools, this article recounts stories of learning-focused teacher leadership in two different PDS partnerships that resulted in positive outcomes for kindergarten through fifth grade English Learners (EL) and for ninth grade algebra students. Supported by research, the stories illustrate how providing embedded support and opportunities for teacher leadership through the PDS core practices of teacher preparation, professional development, inquiry and research, and student learning is advantageous for both teachers and students.
\end{abstract}

Keywords: algebra, English Learners (EL), professional development schools (PDS), student learning, teacher leadership

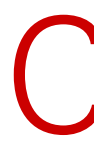

onsider four scenarios from the book Teacher Leadership in Professional Development Schools (Hunzicker, 2018a):

- In Ohio, a teacher leads her grade level team in creating a continuous improvement plan that later serves as an exemplary countywide model.

- In New Jersey, a professor-in-residence provides on-site instructional support for new teachers.

- In Indiana, a mid-career teacher opens her classroom to senior-year teaching interns enrolled at a local university.

- In Maryland, a school-university team works together to implement a schoolwide action plan for encouraging restorative practices.

What do these scenarios have in common? Each one offers a glimpse of learning-focused teacher leadership within the context of a professional development school (PDS) partnership.

\section{What is PDS?}

More than just a friendly relationship between a P-12 (preschool through twelfth grade) school and a college or university, professional development schools (PDS) were first established in the 1990s to encourage innovation and sustainable practices related to four core practices: teacher preparation, professional development, inquiry and research, and student learning
(Holmes Group, 1986, 1990; Rutter, 2006). Ranging in size from a single school to multi-district networks, PDS partnerships offer mutual benefits to school and university through professional collaboration and resource sharing to support continuous learning (Ferrara, 2014). For example, university partners might provide professional development such as guided inquiry, along with other forms of support such as instructional coaching, in exchange for clinical placements for preservice teachers. In this way, P-12 teachers benefit from the theoretical knowledge provided by university faculty, and university faculty and students benefit from the practitioner knowledge of P-12 teachers (Hartzler-Miller, 2006).

The National Association for Professional Development Schools (NAPDS) recommends that in addition to embedding the four core practices, PDS partnerships develop formal structures and governance based on Nine Essentials of a PDS (NAPDS, 2008):

1. A comprehensive mission that is broader in its outreach and scope than the mission of any partner and that furthers the education profession and its responsibility to advance equity within schools and, by potential extension, the broader community;

2. A school-university culture committed to the preparation of future educators that embraces their active engagement in the school community; 
3. Ongoing and reciprocal professional development for all participants guided by need;

4. A shared commitment to innovative and reflective practice by all participants:

5. Engagement in and public sharing of the results of deliberate investigations of practice by respective participants;

6. An articulation agreement developed by the respective participants delineating the roles and responsibilities of all involved;

7. A structure that allows all participants a forum for ongoing governance, reflection, and collaboration;

8. Work by college/university faculty and P-12 faculty in formal roles across institutional settings; and

9. Dedicated and shared resources and formal rewards and recognition structures.

By incorporating the four core practices and as many of the Nine Essentials as possible, PDS partnerships are distinguished as a specific type of school-university partnership. The authors of the Nine Essentials explain:

The essentials are written in tangible, rather than abstract, language and represent practical goals toward which PDS work should be directed. For those in established PDSs, some aspects of current work will be confirmed while other aspects may be identified as needing attention. For those aspiring to establish PDSs, we offer this statement as a useful guide for their work (NAPDS, 2008, Foreword).

The Nine Essentials were written to allow each PDS partnership to develop organically based on the mutual needs and available resources of both school and university. As one example, partners at a university in Virginia differentiated their PDS network by offering three partnership pathway options: Partner sites host pre-service teachers during early fieldwork; clinical practice sites host student teachers and interns; and collaborative inquiry sites are provided with an on-site university facilitator who supervises student teachers and interns and assists practicing teachers with inquirybased research (Parker, Parsons, Groth, \& Brown, 2016).

Recent efforts to bolster teacher preparation, retain quality teachers, and support school reform have created renewed interest in PDS partnerships across the United States (American Association of Colleges for Teacher Education [AACTE], 2018). Research aimed at exploring teacher leadership in PDS partnerships is also gaining momentum (Cosenza, 2018; McCully, 2017; Rutter \& Leon, 2018). Following a brief literature review connecting PDS, professional development, and teacher leadership, this article draws from the book Teacher
Leadership in Professional Development Schools to recount stories of learning-focused teacher leadership in two different PDS partnerships that resulted in positive outcomes for kindergarten through fifth grade English Learners (EL) in New York City and for ninth grade algebra students in South Carolina.

\section{PDS and Professional Development}

Research shows that effective professional development for teachers is active and collaborative, embedded within teachers' work, and extended over weeks and months (Darling-Hammond, Hyler, \& Gardner, 2017; Drago-Severson, 2009). Effective professional development also incorporates modeling and coaching with frequent opportunities for feedback and reflection (Darling-Hammond et al., 2017). Desimone (2011) describes embedded professional development as on-the-job learning opportunities that are directly related to teachers' work, such as "coteaching, mentoring, reflecting on lessons, group discussions of student work, a book club, a teacher network, or a study group" (p. 69). Teaching-related work such as action research, designing new curriculum, and engaging in school improvement initiatives also serves as professional development when teachers gain knowledge and skills through their efforts (Desimone, 2011). When job-embedded professional development is collaborative, teachers' leadership skills often develop as well (Hunzicker, 2012).

By encouraging innovation and modeling best instructional practices, PDS partnerships offer distinctive professional learning environments for teachers (Neapolitan \& Levine, 2011). When best practices are implemented in PDS classrooms, pre-service teachers gain exposure to research-based practices; experienced teachers deepen their teaching knowledge and span school-university boundaries; and students benefit from learning experiences that are interactive, differentiated, inquiry-based, and relevant (Burns, Yendol-Hoppey, Nolan, \& Badiali, 2013; Miller, 2015). In such rich school environments, teacher leaders emerge, develop, and thrive.

\section{Teacher Leadership}

York-Barr and Duke (2004) define teacher leadership as "the process by which teachers, individually or collectively, influence their colleagues, principals, and other members of the school community" (pp. 287-288). Teacher leadership can be exercised formally or informally. Shillingstad and McGlamery (2019) elaborate:

Teacher leadership in schools across the nation is practiced inside and outside of the classroom, through informal and formal positions and 
various roles and responsibilities. Teachers may serve in formal leadership roles such as mentors, administrative assistants, department chairs, school improvement team leaders, or curriculum specialists. Leadership roles may be demonstrated in informal ways through coaching peers, participating in small groups and teams, or modeling best practice (p. 25).

Teacher leaders tend to be exemplary teachers who prioritize students' needs and concerns (Danielson, 2006; Silva, Gimbert, \& Nolan, 2000). Because teacher leaders tend to work alongside fellow teachers to provide guidance and support (Lieberman \& Friedrich, 2007), they have natural credibility with their peers (Carver, 2016) that allows them to positively influence teaching and learning beyond their own classrooms. For example, when instructional leadership responsibilities are distributed to experienced teachers, principals have more time to focus on administrative concerns (Illinois P-20 Council, 2016).

When teacher leadership is systematically supported, both teachers and students benefit. A district-wide study of teacher leadership in lowa revealed that implementation of a statewide teacher leadership and compensation initiative resulted in more support for teacher leaders, more opportunities for teacher leadership, and increased feelings of teacher efficacy around classroom instruction and student learning (Eckert \& Daughtrey, 2019). Benefits to teachers and students have even greater potential in PDS partnerships due to the distinctive professional learning environment of PDS.

\section{Teacher Leadership in PDS}

Teacher leadership in PDS is defined as "a strategic, process-oriented stance motivated by deep concern for students and activated through formal, informal, and hybrid leadership roles that span the boundaries of school, university, and community" (Hunzicker, 2018b, p. 24). A study of distributed leadership in one PDS network found that PDS principals' delegation of leadership responsibilities to teachers empowered veteran teachers to participate in decision-making; created interdependence between principals and teacher leaders; and increased teachers' involvement in professional development, school reform efforts, and special PDS opportunities such as teaching a college course (Larsen \& Reickhoff, 2014).

In PDS partnerships, opportunities abound for teachers to assume learning-focused leadership roles such as team lead, instructional coach, and professional developer. Moreover, when teachers collaborate around issues of teaching and learning, they develop and refine their leadership skills (Shillingstad \& McGlamery, 2019; Vernon-Dotson \& Floyd, 2012). As a result, teachers who actively engage in PDS work often emerge as teacher leaders (Lecos, Cassella, Evans, Leahy, Liess, \& Lucas, 2000; Vernon-Dotson \& Floyd, 2012).

PDS partnerships nurture teacher leadership by giving teachers the time, resources, and authority to collaboratively identify problems, generate solutions, and pursue efforts related to their students, classrooms, and curricula (Rutter \& Leon, 2018). For example, in a Maryland PDS initiative, college professors and experienced classroom teachers worked together over several months' time to uncover troubling problems of practice and develop strategies for addressing them (Kruft \& Wood, 2018). Taking initiative, engaging in collaborative inquiry, and sharing results are embedded within the PDS culture, making professional risk taking and innovation the norm. When teachers in PDS are empowered to initiate improvements related to teaching and learning, higher quality teaching, improved student achievement, and better schools often result (Carpenter \& Sherretz, 2012).

There is much to learn about teacher leadership by studying the work of teachers in PDS partnerships (Frick, Polizzi, \& Frick, 2009; Hunzicker, 2018b; Larsen \& Rieckhoff, 2014). The following accounts of learningfocused teacher leadership in two different PDS partnerships illustrate the positive outcomes that can result when teacher leaders take initiative on behalf of students.

\section{Meeting the Needs of English Learners}

The population of racially and ethnically diverse students continues to increase in public schools across the United States, yet students identified as English learners (ELs) consistently perform lower on standardized tests than students whose native language is English (de Brey, Musu, McFarland, Wilkinson-Flicker, Diliberti, Zhang, Branstetter, \& Wang, 2019). In New York City, three teacher leaders from Public School 291 and a PDS liaison from Lehman College collaborated to address the needs of kindergarten through fifth grade English learners (ELs) by hosting pre-service teacher candidates in their classrooms and mentoring them on best practices for promoting ELs' learning (Dubetz, Fella, LaChapell, \& Rivera, 2018). However, the three teachers could only reach a small number of pre-service teacher candidates each semester. To share their expertise more broadly, two of the teachers worked with the PDS liaison to digitally record their teaching. The recordings were edited into brief segments and aligned with core teaching practices for ELs before being organized into online modules for pre-service teacher candidates to view during their teaching methods courses. 
Upon learning about the videos, the team was invited by school administrators to plan and implement professional development for practicing teachers. Their first professional learning series introduced and exemplified core teaching practices for ELs, such as frontloading academic language instruction, to help teachers design instructional and assessment strategies for developing students' language proficiency. A second series showed teachers how to use the newlydeveloped strategies and assessments to prepare $E L$ students for the state achievement test.

The team also supported teachers in their classrooms with modeling, co-teaching, coaching, and group consultation. As the school year continued, participating teachers reported that they were successfully using the team-created strategies and assessments, and their efforts paid off. Their EL students' state test scores showed improvement in reading at all grade levels, improvement in English speaking proficiency in four of five grade levels, and improvement in writing at three of five grade levels. Moreover, because these teacher leaders worked in a PDS, they were afforded an opportunity to share their instructional expertise beyond their classrooms, first through videos of their teaching and later through schoolwide professional development. In addition to positively influencing pre-service and practicing teachers, this school-university team made a lasting impact on the learning and achievement of EL students schoolwide.

\section{De-tracking Ninth Grade Algebra}

Tracking, or grouping students in classes based on their academic ability, is a common practice in American high schools even though research warns that tracking disadvantages low-achieving students, low income students, and students of color (Archbald \& Keleher, 2008). At a suburban PDS partnering with the University of South Carolina, a high school math teacher noticed that a disproportionate number of low-income students and students of color were being recommended for a developmental, pre-algebra math course instead of the standard college preparatory Algebra I course. Intrigued by self-fulfilling prophecy theory, which observes the influence of teachers' expectations on student performance, the teacher received permission from school administrators to launch a year-long pilot project (Jeffries, 2018). Fortynine ninth grade students who were tracked into the teacher's developmental pre-algebra class (the prerequisite course for Algebra I) were told that they were enrolled in Algebra I. Throughout the school year, they were taught and assigned the grade level, college preparatory work required of Algebra I students. When final grades were calculated, $83.2 \%$ of the students who participated in the pilot project passed Algebra I.

Inspired, the teacher, the principal, and the school's PDS liaison met to begin planning for gradewide implementation of the project. During the summer months, eight Algebra I teachers worked with the school's guidance counselors to create a modified block schedule that would allow pre-algebra students to receive 45 minutes of pre-teaching as a required elective, followed by 45 minutes of Algebra I. While enrollment in the elective classes was exclusively for students tracked into pre-algebra, the Algebra I classes included a mix of pre-algebra- and college preparatorytracked students.

The grade-wide implementation plan employed a mastery learning approach based on 13 learning objectives. Other supportive structures included synchronized curriculum, lesson plans, and assessments; proactive parent communications; and weekly team meetings throughout the school year. Again, the project was successful. Following one year of grade-wide implementation, $86.6 \%$ of students tracked into pre-algebra passed the college preparatory Algebra I course; and after two years, the pass rate increased to $90.1 \%$, which exceeded the pass rate of the traditional tracking system. Because this visionary teacher worked in a PDS, she was able to secure the permissions and resources needed to innovate on behalf of traditionally underserved students. Beginning with her own classroom, she used her successful instructional experience to scale up the initiative, positively impacting student achievement and faculty teaching practices across an entire grade level.

\section{Discussion}

These stories of learning-focused teacher leadership illustrate how PDS partnerships offer distinctive learning environments for teachers by encouraging innovation and modeling best instructional practices that can be replicated and sustained over time. In both stories, teachers noticed a problem, developed a solution, and took action to ensure that students would be better served. Danielson (2006) explains such teacher leader motivation as follows:

These teachers... are committed to teaching...but they also recognize that they have more to offer the profession if they extend their gaze beyond the walls of their own classrooms and initiate projects that will improve the educational program for all students in their school and perhaps for students beyond that boundary (To Teacher Leaders and their Administrators). 


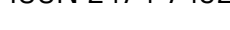

The student-centered, job-embedded leadership work in which these teachers engaged was learning-focused, aligning directly with Desimone's (2011) core features of effective professional development. In both stories, teachers' efforts were content-focused (reading and algebra); involved active learning on the part of both the teacher leaders and those whom they led; were coherent (or consistent with the schools' and the PDS partnerships' mission and goals); extended one school year or more in duration; and involved the collective participation of teachers, administrators, and others grade- or schoolwide. In both cases, learning-focused teacher leadership benefitted students, teachers, and in one case, pre-service teachers as well.

The Nine Essentials of PDS (NAPDS, 2008) further illuminate the empowerment of the PDS learning environment in these stories. Because these teachers worked within PDS partnerships, they felt free to innovate; and when they did they received timely and necessary support from both their school administrators and their university liaisons. Ultimately, this support enabled them to institutionalize best instructional practices (Essential 1) through schoolwide professional development, restructuring, and improved instruction and assessment (Essentials 2, 3, 4, 8, and 9). Later, these teachers worked with their university liaisons to chronicle their successes by writing chapters for publication in the book Teacher Leadership in Professional Development Schools, which extended their positive influence on teaching and learning even further (Essentials 1 and 5). About Essential 5, the authors of the NAPDS Nine Essentials of PDS write, "In addition to routinely examining best practice, PDS participants also share their work with others, both within and outside of their PDS, as a way of contributing to the educational dialogue" (NAPDS, 2008, p. 6). By sharing their work widely, the teacher leaders in these stories provided inspiration and instructional models for others to consider, adapt, and pursue.

\section{Concluding Remarks}

Burns (2018) writes, "Change cannot be the sole responsibility of teachers or schools. Rather, it must be a shared endeavor between those currently working with $\mathrm{K}-12$ students and those preparing for the next generation of educational professionals" (pp. 277278). As these stories illustrate, providing embedded support and opportunities for teacher leadership through the PDS core practices of teacher preparation, professional development, inquiry and research, and student learning is advantageous for both teachers and students. Indeed, in the rich school environments of PDS, teacher leaders emerge, develop, and thrive. This

\author{
2019, Vol. 4, No. 1
}

is what teacher leaders in PDS do. This is the PDS advantage.

Author's note: For detailed, firsthand accounts of both stories, please see chapters 3 and 4 of the book Teacher Leadership in Professional Development Schools, Emerald Publishing, 2018.

\section{References}

American Association for Colleges for Teacher Education (2018). A pivot toward clinical practice, its lexicon, and the renewal of educator preparation: A report of the AACTE Clinical Practice Commission. Retrieved from http://www.nysed.gov/common/nysed/files/cpcaactecpcreport.pdf

Archbald, D., \& Keleher, J. (2008). Measuring conditions and consequences of tracking in the high school curriculum. American Secondary Education, 36(2), 26-42.

Burns, R. W. (2018). Teacher leader preparation and development in PDS: Themes and recommendations. In J. Hunzicker (Ed.), Teacher Leadership in Professional Development Schools (pp. 277-288). Bingley, UK: Emerald Publishing.

Burns, R. W., Yendol-Hoppey, D., Nolan, J. F., \& Badiali, B. J. (2013). Let's learn together. Phi Delta Kappan, 94(7), 26.

Carpenter, B. D., \& Sherretz, C. E. (2012). Professional development school partnerships: An instrument for teacher leadership. SchoolUniversity Partnerships, 5(1), 89-101.

Carver, C. L. (2016). Transforming identities: The transition from teacher to leader during teacher leader preparation. Journal of Research on Leadership Education, 11(2), 158-180.

Cosenza, M. (2018). Building leadership capacity: Roles and responsibilities in a PDS. In M. Buchanan and M. Cosenza (Eds.). Visions from Professional Development School Partners: Connecting Professional Development and Clinical Practice (pp. 209-216). Charlotte, NC: Information Age Publishing.

Danielson, C. (2006). Teacher leadership that 


\section{Journal of Interdisciplinary Teacher Leadership}

strengthens professional practice. Alexandria, VA: ASCD.

Darling-Hammond, L., Hyler, M. E., Gardner, M. (2017). Effective teacher professional development. Palo Alto, CA: Learning Policy Institute. Retrieved from https://learningpolicyinstitute.org/product/effecti ve-teacher-professional-development-report

de Brey, C., Musu, L., McFarland, J., Wilkinson-Flicker, S., Diliberti, M., Zhang, A., Branstetter, C., \& Wang, X. (2019). Status and Trends in the Education of Racial and Ethnic Groups 2018 (NCES 2019-038). U.S. Department of Education. Washington, DC: National Center for Education Statistics. Retrieved from https://files.eric.ed.gov/fulltext/ED592833.pdf

Desimone, L. M. (2011). A primer on effective professional development. Phi Delta Kappan 92(6), 68-71.

Drago-Severson, E. (2009). Leading Adult Learning: Supporting Adult Development in our Schools. Corwin: Thousand Oaks, CA.

Dubetz, N., Fella, M., LaChapell,Y., \& Rivera, J. (2018). Collaborative leadership in meeting the needs of English learners in an urban elementary PDS. In J. Hunzicker (Ed.), Teacher Leadership in Professional Development Schools (pp. 4158). Bingley, UK: Emerald Publishing.

Eckert, J., \& Daughtrey, A. (2019). Teacher leadership development: Tracking one district's progress over three years. Education Policy Analysis Archives, 27(42).

Ferrara, J. (2014). Historical context of the PDS movement. In J. Ferrara (Ed.). Professional development schools: Creative solutions for educators (pp. 9-26). Plymouth, UK: Rowman \& Littlefield.

Frick, W. C., Polizzi, J. A., \& Frick, J. E. (2009). Aspiring to a continuous learning ethic: Building authentic learning communities for faculty and administration. Educational Leadership and Administration: Teaching and Program Development, 21, 7-26.
2019, Vol. 4, No. 1

Hartzler-Miller, C. (2006). Response on future directions: Leadership. In J. E. Neapolitan \& T. R. Berkeley (Eds.), Where do we go from here? Issues in the sustainability of professional development school partnerships (pp. 165-176). New York: Peter Lang Publishing, Inc.

Holmes Group (1990). Tomorrow's schools: A report of the Holmes Group. East Lansing, MI: Author.

Holmes Group (1986). Tomorrow's teachers: A report of the Holmes Group. East Lansing, MI: Author.

Hunzicker, J. (Ed.) (2018a). Teacher leadership in professional development schools. Bingley, UK: Emerald Publishing.

Hunzicker, J. (2018b). Teacher leadership in professional development schools: A definition, brief history, and call for further study. In J. Hunzicker (Ed.), Teacher Leadership in Professional Development Schools (pp. 19-37). Bingley, UK: Emerald Publishing.

Hunzicker, J. L. (2012). Professional development and job-embedded collaboration: How teachers learn to exercise leadership, Professional Development in Education, 38(2), 267-289.

Illinois P-20 Council (2016). Teacher Leadership Report: $P$-20 Teacher and Leadership Effectiveness Committee. Retrieved from https://education.illinoisstate.edu/csep/Wallace \%20TL\%20Report\%20Layout\%20FINAL.pdf

Jeffries, R. B. (2018). De-tracking ninth grade algebra: A teacher leadership success story. In J. Hunzicker (Ed.), Teacher Leadership in Professional Development Schools (pp. 5974). Bingley, UK: Emerald Publishing.

Kruft, C., \& Wood, D. (2018). Moving from collaborative teacher inquiry to leadership: Four stories from Project Teacher Leadership. In J. Hunzicker (Ed.), Teacher Leadership in Professional Development Schools (pp. 75-98). Bingley, UK: Emerald Publishing.

Larsen, C., \& Rieckhoff, B. S. (2014). Distributed leadership: Principals describe shared roles in a PDS. International Journal of Leadership in Education, 17(3), 304-326. 


\section{Journal of Interdisciplinary Teacher Leadership}

2019, Vol. 4, No. 1

Lecos, M. A., Evans, C., Leahy, C., Liess, E., \& Lucas, T. (2000). Empowering teacher leadership in professional development schools. Teaching and Change, 8(1), 98-113.

Lieberman, A., \& Friedrich, L. (2007). Teachers, writers, leaders. Educational Leadership, 65(1), 42-47.

McCully, T. M. (2017). PDS and the leader in me. In K. Garas-York, P. del Prado Hill, L. Day, K. Truesdell, and S. Keller (Eds.). Doing PDS: Stories and Strategies from Successful Clinically Rich Practice (pp. 141-145). Charlotte, NC: Information Age Publishing.

Miller, L. (2015). School-university partnerships and teacher leadership: Doing it right. Educational Forum, 79(1), 24-29.

National Association for Professional Development Schools (2008). What it means to be a professional development school. Retrieved from http://napds.org/9\%20Essentials/statement.pdf

Neapolitan, J. E., Levine, M. (2011). Approaches to professional development schools. Yearbook of the National Society for the Study of Education, 110(2), 306-324.

Parker, A. K., Parsons, S. A., Groth, L. A., \& Brow, E. L. (2016). Pathways to partnership: A developmental framework for building PDS relationships. School-University Partnerships, 9(3), 34-48.

Rutter, A., \& Leon, S. (2018). Teacher leadership in a PDS: Think of the possibilities. In M. Buchanan and M. Cosenza (Eds.). Visions from Professional Development School Partners: Connecting Professional Development and Clinical Practice (pp. 217-244). Charlotte, NC: Information Age Publishing.

Rutter, A. (2006). The evolution of the PDS research landscape. In J. E. Neapolitan \& T. R. Berkeley (Eds.), Where do we go from here? Issues in the sustainability of professional development school partnerships (pp. 3-16). New York: Peter Lang Publishing, Inc.
Shillingstad, S. L., \& McGlamery, S. L. (2019). Teachers as leaders: Navigating multiple roles. Delta Kappa Gamma Bulletin, 86(1), 25-38.

Silva, D. Y., Gimbert, B., \& Nolan, J. (2000). Sliding the doors: Locking and unlocking possibilities for teacher leadership. Teachers College Record, 102(4), 779-804

Vernon-Dotson, L. J., \& Floyd, L. O. (2012). Building leadership capacity via school partnerships and teacher teams. The Clearing House, 85, 38-49.

York-Barr, J., \& Duke, K. (2004). What do we know about teacher leadership? Findings from two decades of scholarship. Review of Educational Research, 74(3), 255-31.

\section{About the Author}

Dr. Jana Hunzicker is Associate Dean of the College of Education and Health Sciences at Bradley University. 